TITLE:

\title{
Mycophagy among Japanese macaques in Yakushima: fungal species diversity and behavioral patterns.
}

\section{AUTHOR(S):}

Sawada, Akiko; Sato, Hirotoshi; Inoue, Eiji; Otani, Yosuke; Hanya, Goro

\section{CITATION:}

Sawada, Akiko ... [et al]. Mycophagy among Japanese macaques in Yakushima: fungal species diversity and behavioral patterns.. Primates 2013, 55(2): 249-257

\section{ISSUE DATE:}

2013-12-13

URL:

http://hdl.handle.net/2433/198301

\section{RIGHT:}

The final publication is available at Springer via http://dx.doi.org/10.1007/s10329-0130396-9; この論文は著者最終稿です。内容が印刷版と異なることがありますので、引用 の際には出版社版をご確認ご利用ください。This is the Accepted Author Manuscript. Please cite only the published version. 
1 Mycophagy among Japanese macaques in Yakushima: Fungal species diversity

2 and behavioral patterns

3

4

$5 \quad$ Akiko Sawada $^{\mathrm{a}^{*}}$, Hirotoshi Sato ${ }^{\mathrm{b}}$, Eiji Inoue ${ }^{\mathrm{c}}$, Yosuke Otani $^{\mathrm{a}}$ and Goro Hanya ${ }^{\mathrm{a}}$

6

$7 \quad$ aPrimate Research Institute, Kyoto University, Inuyama, Japan

$8 \quad{ }^{\text {b}}$ Graduate School of Global Environmental Studies, Kyoto University, Kyoto, Japan

$9 \quad{ }^{\mathrm{c}}$ Graduate School of Science, Kyoto University, Kyoto, Japan

$10{ }^{*}$ Corresponding author: Akiko Sawada, Primate Research Institute, Kyoto University,

11 Kanrin 41-2, Inuyama, Aichi 484-8506, Japan. Telephone: +81-568-63-0545, Fax: +81-

12 568-63-0564, E-mail: sawada.akiko.3n@kyoto-u.ac.jp

14 A short title: Mycophagy among Japanese macaques 
15

\section{ABSTRACT}

Mycophagy (fungus-feeding) by Japanese macaques (Macaca fuscata yakui) in

Yakushima has been observed by many researchers, but no detailed information is available on this behavior including which fungi species are consumed. To provide a general description of mycophagy and to understand how and whether macaques avoid poisonous fungi, we conducted behavioral observation of wild Japanese macaques in Yakushima and used molecular techniques to identify fungi species. The results indicate that the diet of the macaques contains a large variety of fungi species (67 possible species in 31 genera), although they compose a very small portion of the total diet composition (2.2\% of the annual feeding time). Fungi which were eaten by macaques immediately after they picked up were less likely to be poisonous than those which were examined (sniffed, nibbled, carefully handled) by macaques. However, such examining behaviors did not appear to increase the macaques' abilities to detect poisonous fungi. Fungi that were only partially consumed included more poisonous species than those fully consumed with/without examining behavior yet this was not significant. Taste, therefore, might also play an important role in discriminating poisonous from non-poisonous.

Key words Japanese macaque; Macaca fuscata yakui; mycophagy; poisonous fungi; fungal diversity 


\section{INTRODUCTION}

While mycophagy has been reported in at least 24 primate species (Hanson et al. 2003; Hanya 2004; Hilário and Ferrari 2010), fungi have received less attention compared with other food items. Fungi usually account for only a small part of the diet composition of most primate species, such as mountain gorillas, bonobos, green monkeys, and Japanese macaques (Harrison 1984; Watts 1984; Bermejo et al. 1995; Hill 1997). According to Hanya (2004), Japanese macaques in the high-altitude coniferous forest of Yakushima, where fruits are less abundant, eat fungi more often than their lowland counterparts. However, no data show whether they feed on specific fungal species.

A few primates are known to consume large quantities of fungi on a regular basis, for example Goeldi’s monkeys and buffy-headed marmosets (Hilário and Ferrari 2010; Porter 2001). Goeldi’s monkeys who mainly consumed fungi that were predominantly fiber (68 - 83\%) have molars with high shearing crests, which might increase their ability to shred fungi into small pieces and thus promote digestion (Porter and Garber 2004; Hanson et al. 2006). Another elucidation for intense mycophagy among Goeldi’s monkeys is as an effective tactic to lower the chance of interspecific competition for fruits with large animals (Porter 2001).

One problem that studies on mycophagy face is fungal species identification. Morphology-based identification is challenging because fungi are quite variable in appearance and many cryptic species exist, as evidenced by the fact that humans around the world occasionally misidentify fungi and are poisoned as a result (Eren et al. 2010; Ishihara and Yamaura 1992; Unluoglu and Tayfur 2003). In this study, we applied DNA-based species identification, which requires no expertise in mycology. Moreover, 
this method allows us to identify the species even from debris that an animal left behind.

Since we do not have to collect intact fruiting bodies to obtain macroscopic and microscopic traits, it is particularly effective in studies on mycophagy by wild animals.

Wild Japanese macaques of Yakushima are an ideal study species for mycophagy because researchers have repeatedly observed them eating fungi (Agetsuma and Noma 1995; Hill 1997; Hanya 2004) and they are well habituated and can be observed from a close distance. Besides, the fungal diversity is high in Yakushima (Tsujino et al. 2009) and many genome sequences of fungi collected there have been added to GenBank, the NIH genetic sequence database (http://www.ncbi.nlm.nih.gov/genbank/), over the past several years. Since DNA-based species identification is a matching process, we can expect reliable results with a large database.

The purposes of this study were (1) to provide a general description of mycophagy among wild Japanese macaques in Yakushima, and (2) to elucidate whether and how macaques avoid poisonous fungi. For the first study purpose, we estimated the diet composition and determined whether the macaques consume a wide variety of fungi. For the second purpose, we focused on detailed mycophagy behaviors, which may reveal whether macaques avoid specific species, namely 'poisonous mushrooms’. Sherrat et al. (2005) indicated that fungi species that are poisonous to humans are more likely to exhibit an unpleasant odor, as judged by humans. Such poisonous species may have a particular taste as it is possibly associated with the odor (Sherratt et al. 2005). Macaques may decide whether to eat the fungi or not based on on-site assessment of such chemical ‘warning’ signals. Alternatively, macaques may have previous knowledge about fungi species that are edible to them, as they do about plant food 
83 items. In order to confirm these two possibilities, we established a set of predictions suggesting that the fungi that macaques did not feed on would be more likely to be poisonous compared with those eaten. Additionally, we provide information on the fungi that macaques consumed repeatedly to explore the possibility of their knowledge

87 about fungi species through previous feeding experiences.

\section{METHODS}

All data collection was non-invasive and permitted by the Yakushima Forest

91 Environment Conservation Center and Kagoshima Prefectural Government. The

92 research adhered to the guidelines established by the Field Research Committee of the

93 Primate Research Institute, Kyoto University ('Guidelines for Studying Wild Primates or Using Wild Primates in Research'), and the legal requirements in Japan.

\section{Study Site and Animals}

Yakushima is a mountainous island located in the southwestern part of Japan $\left(30^{\circ} \mathrm{N}, 130^{\circ} \mathrm{E}\right)$ with an area of $505 \mathrm{~km}^{2}$. Our study site, Hanyama, is part of the Yakushima National Park and is located in the western coastal area of Yakushima (Fig. 1). The study area is covered by subtropical/warm-temperate, evergreen broad-leaved vegetation (Yamagiwa 2008). The mean annual temperature and rainfall (from August 2009 to July 2010) were $20.3^{\circ} \mathrm{C}$ and $3,223.7 \mathrm{~mm}$. The meteorological data were collected at the Yakushima Field Station of Kyoto University in Nagata, which is approximately $8 \mathrm{~km}$ from the study site (Shin-ichiro Aiba, unpublished data).The main study subjects were nine adult females of the AT troop, which consists of seven adult males and thirteen juveniles (1-4 years old). They were individually identified by 
107 physical features. There is no natural predator of wild Japanese macaques in

108 Yakushima, and the macaques are well habituated but not provisioned.

\section{Data Collection}

The study period was from August 2009 to September 2010. We collected the

112 data by focal animal sampling, where we recorded the activity and food item of the

113 focal animal with a 1-min interval to estimate the proportion of mycophagy in the total

114 feeding time. We also calculated annual and monthly diet composition based on this

115 data. For detailed data analysis on mycophagy, we continuously recorded the onset and

116 end of all feeding events (see definition and Table 1). We used all-occurrence sampling

117 of mycophagy and recorded the duration of the feeding/foraging bout. We also collected

118 data on mycophagy by non-focal individuals whenever possible. We used this all-

119 occurrence sampling of focal animals and data for non-focal animals to compile a list of

120 the fungi that macaques consumed and to make a detailed analysis of their mycophagy

121 behavior. Macaques ate fungi off the ground, from decaying logs, or on the trunk of

122 living trees. As fungi have brittle flesh, macaques often dropped small fragments even when they completely consumed the whole fruiting bodies. We collected such fungal samples when available except for cases when macaques did not leave any debris. After coming back to the field station, we placed a small section of each fruiting body sample in $99.5 \%$ ethanol.

We changed focal animals every 180 min with the intention of collecting data from several individuals during a single day. When we lost the focal animal and failed to resume observation within 20 min, we started a new session with a different individual. Here we present the data on the frequency and proportion of mycophagy 
131 related to feeding time that we collected over 223 sessions, amounting to 669 hours in

132 total. We categorized all of the food items eaten by the focal animals as follows: fungi,

133 other fungal materials, seeds, fruits, flowers, leaves, shoots, bark/branches, insects, and

134 others. The category “other fugal materials” refers to the white mycelium found

135 frequently under the bark of dead trees. Leaves include both mature and young leaves.

136 Others consist of herbaceous plants, soil, water, and unidentified items. We calculated

137 monthly dietary composition from a 1-min instantaneous recording of feeding events of

138 the focal animal as the proportion of each food item to the total feeding time. We

139 levelled off August and September, months that data were collected during two calendar

140 years, and calculated annual dietary composition as the average for the 12 months.

\section{Definitions for Mycophagy Behavior}

We defined one foraging event as a period starting when a macaque picked up

144 a fungus and ending when the animal finished handling it. While foraging for fungi,

145 macaques sometimes showed additional conspicuous behaviors such as sniffing,

146 nibbling (no spitting out), and careful handling (splitting a fungi into several pieces;

147 rubbing a fungus with the hands). We defined that macaques examined fungi when they

148 showed at least one of these behaviors.

When a macaque entered within a radius of $1 \mathrm{~m}$ from a fungus, we regarded

150 this as the animal encountering the fungus. We divided behavioral sequences of

151 mycophagy into the following four phases: when a macaque (i) encountered, (ii) picked up, (iii) examined, and (iv) consumed a fungus. At each phase, the macaque chose either of the following two behavioral options: (i) picked up or did not pick up, (ii) examined

154 or did not examine, (iii) ate or did not eat, and (iv) consumed a whole piece of fungus or 
155 ate it only partially. Using these sequences, we classified behavioral patterns into six

156

157

158

159

160

161

162

163

164

165

166

167

168

169

170

171

172

173

174

175

176

177

178

\section{Prediction of Proportion of Poisonous Fungi}

We predicted that fungi that macaques did not eat were more likely to be poisonous if macaques avoided them. We, therefore, compared the proportion of poisonous fungi between the two choices at each phase.

At Phase i, where macaques encountered fungi, the proportion of poisonous species is expected to be higher in fungi that were left untouched (IG) than in those that were picked up (RE + EX-A + EX-P + NE-A + NE-P). At this phase, macaques did not have any physical contact with the fungi. Therefore, they would discriminate poisonous fungi by judging them from knowledge they had acquired through previous feeding experiences.

At Phase ii, where macaques picked up fungi, the proportion of poisonous species is expected to be higher in the fungi examined than in those immediately eaten by macaques $(\mathrm{RE}+\mathrm{EX}-\mathrm{A}+\mathrm{EX}-\mathrm{P}>\mathrm{NE}-\mathrm{A}+\mathrm{NE}-\mathrm{P})$. This suggests macaques would discriminate poisonous fungi based on previous knowledge.

At Phase iii, where macaques examined fungi, the proportion of poisonous species is expected to be higher in fungi rejected than in those eaten by macaques (RE > EX-A + EX-P). This suggests that macaques would discriminate poisonous fungi by examining behaviors. 
At Phase iv, where macaques consumed fungi, the proportion of poisonous

180

181

182

183

184

185

186

187

188

189

190

191

192

193

194

195

196

197

198

199

200

201

202

\section{DNA Extraction, PCR Amplification, and Sequencing}

We extracted total DNA from each fruiting body sample following a modified method described in Sato and Murakami (2008). We added $300 \mu \mathrm{L}$ CTAB buffer to the crushed fungal tissue. After incubating at $55^{\circ} \mathrm{C}$ for $30 \mathrm{~min}$, we added $300 \mu \mathrm{L}$ CIA (chloroform-isoamyl alcohol; 24:1 [vol/vol]) to the mixture and centrifuged it for 15 min at 4,200 rpm. We transferred $100 \mu \mathrm{L}$ clear supernatant to a new microtube, and then with $100 \mu \mathrm{L}$ isopropanol added we centrifuged the mixture for $30 \mathrm{~min}$ at 4,200 rpm. After washing with $70 \%$ ethanol, we dissolved the precipitated DNA in a $50 \mu \mathrm{L}$ TE buffer. We amplified Internal transcribed spacer 2 (ITS2) regions from nuclear ribosomal DNA using the ITS3 and ITS4 primers described by White et al. (1990). We carried out PCR amplification using $1 \mu \mathrm{L}$ total DNA in a $20-\mu \mathrm{L}$ reaction mixture containing Ampdirect Plus (Shimadzu, Kyoto, Japan), 10 pmol of both forward and reverse primers, and 0.5 units of BIOTAQ HS DNA Polymerase (Shimadzu, Kyoto, Japan). Cycling parameters for PCR were as follows: we conducted denaturation at $95^{\circ} \mathrm{C}$ for $10 \mathrm{~min}$, followed by 40 cycles at $94^{\circ} \mathrm{C}$ for $30 \mathrm{~s}, 58^{\circ} \mathrm{C}$ for $30 \mathrm{~s}$, and $72^{\circ} \mathrm{C}$ for 30 s, and followed by a final extension of $2 \mathrm{~min}$ at $72^{\circ} \mathrm{C}$. We added $5 \mu \mathrm{L}$ of $0.05 \times$ ExoSAP- 
203 IT (USB Corp., Cleveland, Ohio) to the PCR products for purification. We incubated

204 the PCR products at $37^{\circ} \mathrm{C}$ for $15 \mathrm{~min}$ and then deactivated the enzymes at $80^{\circ} \mathrm{C}$ for 15

205 min. We sequenced the purified PCR products using the same primers used for

206 amplification. We performed nucleotide sequencing using an ABI 3130 Genetic

207 Analyzer (Applied Biosystems, Foster City, California USA) with BigDye-Terminator

208 v3.1 (Applied Biosystems), following the manufacturer’s protocols.

209

210

Fungal Species Identification

211

We compared the nucleotide sequences obtained with the sequences complied

212 in the NCBI GenBank database. To establish the list of fungi species that the macaques

213 interacted with or ignored, we included the genetic sequences of fungi that were

214 consumed by both focal and non-focal animals as we collected data by all-occurrence

215 sampling. For each sample, we chose the species with the highest bit score when max

216 identity was $97 \%$ or over. Among 478 fungal samples we collected, we successfully

217 obtained the genetic sequences from 398 samples and identified 235 samples to the

218 species level. For credibility of species identification, we did not provide the species

219 name for those with max identity lower than 97\% (82\% for the lowest) but treated them

220 as sp. and used them only for analysis at the genus level. The five most possible

221 candidates suggested by a BLAST search were of the same genus at the rate of $86 \%$ or

222 belonged to one of the genera that were already in our list. Therefore, we believe that

223 we have provided a fairly accurate estimate of the number of fungus genera. 
227 information from a reference book (Imazeki et al. 1988). We admit that the information

228

229

230

231

232

233

234

235

236

237

238

239

240

241

242

243

244

245

on toxicity in the reference books is specific to humans. Due to the similarities in

digestive systems between a Japanese macaque and a human, such as the lack of a foregut fermentation system, we assumed that fungi poisonous to humans are also poisonous to macaques.

\section{RESULTS}

\section{General Features of Mycophagy}

During the observation, all the focal animals consumed fungi. Mycophagy accounted for only $2.2 \%$ of the total feeding time of Japanese macaques over the study period, whereas fruits, leaves, and seeds constituted substantial portions of it (42.6\%, $18.1 \%$, and $11.4 \%$, respectively). There were seasonal changes in their monthly dietary composition (Fig. 2). Frequency of mycophagy reached its highest during May-August, when the macaques mainly fed on fleshy fruits (Myrica rubra) (Table 2). Macaques rarely ate fungi between September and January.

Mycophagy was associated with the feeding time of other fungal materials, fruits and others (other fungal materials: $r=0.58, P<0.05$, fruits: $r=0.83, P<0.001$, others: $r=0.7, P<0.05)$. There was no such correlation between mycophagy and the consumption of other food items (seeds: $r=-0.51, P=0.09$, flowers: $r=0.52, P=0.08$, leaves: $r=0.55, P=0.06$, shoots: $r=0.45, P=0.14$, bark/branches: $r=-0.01, P=0.97$, insects: $r=-0.2, P=0.54)$.

The total numbers of fungi species and genera that the macaques actually consumed (at least partially) were 67 and 31, respectively (Table 3, Appendix). 
250 Eighteen species (18 genera) were ignored by macaques and 25 species (11 genera)

251

252

253

254

255

256

257

258

259

260

261

262

263

264

265

266

267

268

269

270

271

272 were rejected. Among these 110 species (51 genera), 40 species (23 genera) are

described in the reference book (Imazeki et al. 1988). The number of fungi ignored by

macaques is underestimated because, by definition, fungi were supposed to be large

enough to be found with the naked eye. Furthermore, considering that all of the fungi

we recorded were located less than 1-m away from macaques, it was unlikely that

neither macaques nor the observers missed many fungi. Therefore, we assume that those

fungi were left untouched because the macaques were not interested in them, rather than simply overlooking them.

\section{Behavioral Patterns}

Japanese macaques generally consumed fungi without examining behaviors

(Table 2). The proportion of poisonous fungi species in the total number of fungi they picked up was not significantly different from that in the total number of fungi they ignored. (Phase i: $P=1$, Fig. 3). The proportion of poisonous species was significantly higher among the fungi examined by the macaques compared with the fungi they ate immediately (Phase ii: $P<0.0001)$. However, when they exhibited examining behaviors, the proportion of poisonous species did not differ between the rejected fungi and the eaten fungi (Phase iii: $P=1$ ). A marginally significant trend was found in fungi that were completely consumed compared with those only partially eaten by macaques with examining behaviors (Phase iv: $P=0.086$ ). The same pattern was found when they did not exhibit examining behaviors while eating, yet this difference was also marginally significant (Phase iv: $P=0.074$ ). 
274 repeated consumption of the same species. We pooled behavioral patterns for each

275

276

277

278

279

280

281 species, and thus no individual difference is mentioned here. When the macaques encountered the same species multiple times, they tended to show similar behavioral patterns. For example, when they encountered the same species twice (18 species), the proportion showing the same behavioral pattern was 61\%, which was much higher than the chance level $(1 / 6)(P<0.0001$, binomial test). The same was true for fungi eaten three times (25\% of eight species, $P=0.019)$ and four times (25\% of five species, $P=$ 0.023). The same pattern was not found for species eaten more than four times (five times: $0 \%$ of three species, $P=1$; six times: $0 \%$ of six species, $P=1$; nine times: $0 \%$ of one species, $P=1$; 27 times: one species, $P=1$ ). When combining the six categories into two, based on whether the macaques consumed the fungus (NE-A, NE-P, EX-A, EX-P) or not (IG, RE), there was a stronger tendency for macaques to show the same response to the same species. The proportion of showing only either of the two behaviors became significantly higher than the chance level for the species the macaques encountered twice (15 out of 18 species, $P<0.01$, binomial test), three times (five out of eight species, $P<0.05$ ), five times (three out of three species, $P<0.001$ ), six times (two out of six species, $P<0.05$ ), nine times (one out of one species, $P<$ 0.005), and 27 times (one out of one species, $P<0.0001$ ). The only exception was the species encountered exactly four times, where there was no such tendency (two out of three species, $P=0.12$ ).

\section{DISCUSSION}

General Features of Mycophagy among Japanese Macaques 
portion of feeding time, which might be explained by their relatively large body size compared with other intensively mycophagous primates. Mycophagy by the macaques constituted only $2.2 \%$ of the annual feeding time and $4.5 \%$ during the peak month (June). These findings correspond to general patterns in mycophagy among primates, where fungi are generally not important food resources (Hanson et al. 2003). For example, fungi account for $1.2 \%$ of the annual feeding time in green monkeys, $0.2 \%$ in mountain gorillas, and 1.7\% in bonobos (Bermejo et al. 1995; Harrison 1984; Watts 1984). On the other hand, Goeldi’s monkeys and buffy-headed marmosets are exceptionally strong mycophagous primates. The average feeding time on fungi by Goeldi's monkeys is 31\%, which reaches 65\% during the peak month (Porter 2001), and that by buffy-headed marmosets is $64.8 \%$ and $70.2 \%$, respectively (Hilário and Ferrari 2010). These animals are much smaller (Goeldi’s monkeys: 400-535 g, buffy-headed marmosets: 406 g) compared with other primates known to eat fungi, such as gorillas (97.9-159.2 kg), bonobos (31.0-39.0 kg), and vervet monkeys (3.3-4.6 kg) (Rowe and Mittermeier 1996). Patchy distribution and the smaller food-patch size of fungi make it

313 difficult for them to be the main or fallback food resources for larger animals.

314 Interestingly, there is also a relationship between mycophagy and body size among marsupials, where large species tend to become less mycophagous (Johnson 1996).

316 Considering the fact that Japanese macaques (8.3-18.0 kg) are larger than most of those 317 small mycophagous primates and marsupials, their low mycophagy frequency appears 318 to be consistent with this pattern. The fact that fungi constituted $14 \%$ of the diet of Japanese macaques in a harsh environment with lower fruit availability (Hanya 2004) indicates that environmental factors also contribute to mycophagy frequency. Fungi are 
nonetheless still not as important to those macaques as they are to small mycophagous

322

323

324

325

326

327

328

329

330

331

332

333

334

335

336

337

338

339

340

341

342

343

344 animals.

There was a positive correlation between the consumption of fungal fruiting bodies and fungal materials. This consistency may reflect fungal emergence patterns as both are categorized as fungi. Previous studies showed that fungal fruiting emergence in evergreen broad-leaved forests in Japan is a seasonal event that is affected by temperature and rainfall (Tsujino et al. 2009; Murakami 1989). Mycophagy was also associated with the feeding time of fruits. Macaques consumed fungi most often during May-August while their main food items were fleshy fruits of M. rubra. M. rubra fruits are highly preferred by Japanese macaques (Agetsuma and Noma 1995), and they reached up to $60 \%$ of their diet during the peak month in this study. Fungi therefore are not a fallback food, which is defined as a food eaten during times when preferred foods are scarce. During the research period, we observed macaques fighting over a fungus at least twenty times. These findings suggest the notion that fungi are valuable foods for macaques. The high protein values of some fungi (Agrahar-Murugkar and Subbulakshmi 2005) might be related to this tendency, while simple-stomach macaques without strong fermentation system may not readily derive such proteins from fungi (Hanson et al. 2006). Since the nutritional quality varies among fungi species, further analysis of the nutritional values of fungi might help us to understand why macaques desire fungi.

Japanese macaques in Yakushima consumed an enormous variety of fungi (possibly 67 species of 31 genera). This could rise further if fungal samples were available from all mycophagy events. Yet, the numbers are still astonishing compared with other mycophagous primates such as Goeldi's monkeys, which consume only four 
species (Hanson et al. 2003). Even northern flying squirrels, primarily mycophagous mammals, feed on fungi of only 23 genera (Lehmkuhl et al. 2004). This fact indicates that Japanese macaques interact with more species of fungi via mycophagy than do frequent mycophagous mammals. Why do Japanese macaques consume such a diversity of fungi? Since the macaques move/feed both on the ground and in the trees, they have more chances to find fungi compared to highly arboreal species. Diversified mycophagy among macaques might also reflect the high fungal diversity in Yakushima (Tsujino et al. 2009). Our reasoning is based on the assumption that macaques are opportunistic when eating fungi rather than being selective mycophagists. In fact, when macaques encounter a fungus, they usually ingest it without exhibiting examining behaviors, although they also exhibit avoidance of poisonous fungi to some degree (see below). Since few sites have accumulated a body of data on fungus availability in regard to species diversity comparable to that in Yakushima (Tsujino et al. 2009), further studies are needed before drawing concrete conclusions.

\section{Behavioral Patterns: Exclusion of Poisonous Fungi}

Our findings indicate the possibility that Japanese macaques can discriminate

364 Therefore, macaques seemed to use mixed tactics to avoid poisonous fungi based on

365 both previous knowledge and on-site assessment of taste, and neither alone was sufficient to discriminate poisonous fungi perfectly. 
369 be non-poisonous. However, the fungi examined by the macaques were more likely to

370 be poisonous than those eaten immediately. These findings suggest the possibility that macaques visually discern poisonous fungi based on knowledge they have acquired through previous feeding experiences. There were nine cases of the macaques eating poisonous fungi after showing examining behaviors, indicating that poisonous fungi were not always excluded at the first phase. At the second phase, the rest of the poisonous fungi were screened out except for one case. The macaques are likely to screen out poisonous fungi by actually taking a few bites on the spot, possibly judging from the taste and smell. We failed to find statistical significance for this finding because most of the poisonous fungi had already been excluded at the first phase. useful for eliminating poisonous fungi (Phase iii). Examination of bibliographic descriptions of fungi in North America and Europe reveal that poisonous species are more likely to emit distinctive odors, which might have evolved as warning odors to enhance avoidance learning by mycophagists (Sherratt et al. 2005). Our research shows that macaques cannot perceive such warning odors. Therefore, warning odors emanating from poisonous fungi do not function as a deterrent to mycophagy for Japanese macaques.

Behavioral Consistency and Possibility of Group Learning 
393 individual or among-group level. For example, there were some cases where the same

394 individual consumed a particular fungus repeatedly. Among the nine individuals who ate Crepidotus mollis, the most frequently eaten species, all the nine animals showed the same tendency as to whether they ate or did not eat. In a detailed evaluation with six categories, seven individuals consumed it more than twice and four of them always showed the same behavior (NE-A). Although there were some consistencies as we suggested, their behavioral patterns were not universal and hence we should admit other interpretations. Macaques may make on-site assessments of fungi on a case-by-case basis rather than depending on unequivocal cues. degree of knowledge about poisonous fungi species. This finding would lead us to a legitimate question about the possible process of knowledge acquisition and how and whether macaques would share such information. There were cases where mothers joining their offspring in eating fungi, and vice versa. We also observed a 1-year-old male, who was watching his mother eating a fungus, got a piece left by his mother. We could not obtain enough evidence to evaluate their memory or learning performance. However, these instances imply possibilities for group learning, which is crucial, especially for immatures. A study on red squirrels suggests that naive animals, who have not yet learned what not to eat, may fail to avoid poisonous fungi (Camazine et al. 1983). Further research to explore how young animals acquire knowledge about fungi may reveal the mechanism of group learning. 
417 yet it is an act of minor importance from a quantitative viewpoint. When macaques

418 ingest a fungal fruiting body immediately without showing examining behaviors, it is

419 highly unlikely to be poisonous. Macaques therefore might have knowledge of the fungi

420 that are edible to them. They eliminate poisonous fungi by taste, while examining

421 behaviors do not function effectively to exclude poisonous species. Behavioral

422 consistency observed in repeated eating of certain species also indicates that the

423 macaques might share common knowledge of some fungi species as food resources. 
425

426

427

428

429

430

431

432

433

434

435

436

437

438

439

440

441

442

443

\section{ACKNOWLEDGMENTS}

The authors would like to express their gratitude to Drs. K. Watanabe, T.

Furuichi, H. Imai and E. Sakaguchi for their great advice for this study. We are grateful to the members of Department of Ecology and Social Behavior for their informative comments and advice. We are thankful to Mr. T. Saito for his great help in establishing phenology plots and to Yakushima Forest Environment Conservation Center and Kagoshima Prefectural Government for permission to carry out field research and sample collection on in Yakushima. We also thank all our colleagues and friends who visited and stayed at Yakushima Field Station, Wildlife Research Center of Kyoto University, for sharing their valuable information and insights. This study was financially supported by JSPS-MEXT Grant-in-Aid for JSPS Fellows (No. 225374) to AS, JSPS-MEXT Grant-in-Aid for Challenging Exploratory Research (No. 23657018) and for Young Scientists (No. 20770195) to GH, and Global COE Program "Formation of a Strategic Base for Biodiversity and Evolutionary Research: from Genome to Ecosystem”.This research adhered to the ASP Principles for the Ethical Treatment of Nonhuman Primates and complied with the guidelines established by KUPRI and the legal requirements in Japan. 
444

445

446

447

448

449

450

451

452

453

454

455

456

457

458

459

460

461

462

463

464

465

466

467

\section{REFERENCES}

Agetsuma N, Noma N (1995) Rapid shifting of foraging pattern by Yakushima macaques (Macaca fuscata yakui) in response to heavy fruiting ofMyrica rubra. International Journal of Primatology 16 (3):247-260.

Agrahar-Murugkar D, Subbulakshmi G (2005) Nutritional value of edible wild mushrooms collected from the Khasi hills of Meghalaya. Food Chemistry 89 (4):599-603.

Bermejo M, Illera G, Pí JS (1995) Animals and mushrooms consumed by bonobos (Pan paniscus): New records from lilungu (Ikela), Zaire. International Journal of Primatology 16 (1):879-898.

Camazine S, Resch J, Eisner T, Meinwald J (1983) Mushroom chemical defense. J Chem Ecol 9 (10):1439-1447.

Eren SH, Demirel Y, Ugurlu S, Korkmaz I, Aktas C, Güven FMK (2010) Mushroom poisoning: retrospective analysis of 294 cases. Clinics 65:491-496.

Hanson A, Hall M, Porter L, Lintzenich B (2006) Composition and Nutritional Characteristics of Fungi Consumed by Callimico goeldii in Pando, Bolivia. International Journal of Primatology 27 (1):323-346.

Hanson AM, Hodge KT, Porter LM (2003) Mycophagy among primates. Mycologist 17 (1):6-10.

Hanya G (2004) Diet of a Japanese Macaque Troop in the Coniferous Forest of Yakushima. International Journal of Primatology 25 (1):55-71.

Harrison M (1984) Optimal foraging strategies in the diet of the green monkey, Cercopithecus sabaeus, at Mt. Assirik, Senegal. International Journal of Primatology 5 (5):435-471. 
468

469

470

471

472

473

474

475

476

477

478

479

480

481

482

483

484

485

486

487

488

489

490

Hilário RR, Ferrari SF (2010) Feeding ecology of a group of buffy-headed marmosets (Callithrix flaviceps): fungi as a preferred resource. American Journal of Primatology 72 (6):515-521.

Hill DA (1997) Seasonal variation in the feeding behavior and diet of Japanese macaques (Macaca fuscata yakui) in lowland forest of Yakushima. American Journal of Primatology 43 (4):305-320.

Imazeki R, Otani Y, Hongo T (1988) Fungi of Japan. Yama-Kei Publishers (in Japanese), Tokyo.

Ishihara Y, Yamaura Y (1992) Descriptive epidemiology of mushroom poisoning in Japan (in Japanese). Japanese Journal of Hygiene 46 (6):1071-1078.

Johnson CN (1996) Interactions between mammals and ectomycorrhizal fungi. Trends in Ecology \& Evolution 11 (12):503-507.

Lehmkuhl JF, Gould LE, Cázares E, Hosford DR (2004) Truffle abundance and mycophagy by northern flying squirrels in eastern Washington forests. Forest Ecology and Management 200 (1-3):49-65.

Murakami Y (1989) Spatial changes of species composition and seasonal fruiting of the Agaricales in Castanopsis cuspidata forest [Japan]. Transactions of the Mycological Society of Japan 30.

Porter L (2001) Dietary Differences Among Sympatric Callitrichinae in Northern Bolivia: Callimico goeldii, Saguinus fuscicollis and S. labiatus. International Journal of Primatology 22 (6):961-992.

Porter LM, Garber PA (2004) Goeldi's monkeys: A primate paradox? Evolutionary Anthropology: Issues, News, and Reviews 13 (3):104-115. 
491

492

493

494

495

496

497

498

499

500

501

502

503

504

505

506

507

508

509

510

511

512

Rowe N, Mittermeier RA (1996) The Pictorial Guide to the Living Primates. Pogonias Press, East Hampton, New York.

Sato H, Murakami N (2008) Reproductive isolation among cryptic species in the ectomycorrhizal genus Strobilomyces: Population-level CAPS marker-based genetic analysis. Molecular Phylogenetics and Evolution 48 (1):326-334.

Sherratt TN, Wilkinson DM, Bain RS (2005) Explaining Dioscorides' "double difference": why are some mushrooms poisonous, and do they signal their unprofitability? The American Naturalist 166 (6):767-775.

Tsujino R, Sato H, Imamura A, Yumoto T (2009) Topography-specific emergence of fungal fruiting bodies in warm temperate evergreen broad-leaved forests on Yakushima Island, Japan. Mycoscience 50 (5):388-399.

Unluoglu I, Tayfur M (2003) Mushroom poisoning: an analysis of the data between 1996 and 2000. European Journal of Emergency Medicine 10 (1):23-26.

Watts DP (1984) Composition and variability of mountain gorilla diets in the Central Virungas. American Journal of Primatology 7 (4):323-356.

White TJ, Bruns T, Lee S, Taylor J (1990) Amplification and direct sequencing of fungal ribosomal RNA genes for phylogenetics. In: Innis MA, Gelfand DH, Sninsky JJ, White TJ (eds) PCR protocols: a guide to methods and applications. Academic Press, San Diego, California, pp 315-322.

Yamagiwa J (2008) History and Present Scope of Field Studies on Macaca fuscata yakui at Yakushima Island, Japan. International Journal of Primatology 29 (1):49- 
Table 1: Definition of mycophagy by Japanese macaques

\begin{tabular}{|l|l|}
\hline Behavioral categories & Definitions \\
\hline Ignore (IG) & Not touching a mushrooom that was found within a 1-m radius of the animal * \\
\hline Reject (RE) & $\begin{array}{l}\text { Examining a mushroom but not eating it. Might take a bite but spit it out (no } \\
\text { ingestion) }\end{array}$ \\
\hline Examine, eat all (EX-A) & Showing examining behaviors while/before consuming the whole mushroom \\
\hline Examine, eat partially (EX-P) & Same as Ex-A except for mushroom consumption is only partially \\
\hline Not examine, eat all (NE-A) & Consuming the whole mushroom whithout examining behaviors \\
\hline Not examine, eat partially (NE-P) & $\begin{array}{l}\text { No examining behavior observed while ingesting a mushroom. Only a part of the } \\
\text { mushroom or some of the multiple mushrooms avaiable are ingested }\end{array}$ \\
\hline * Note that the number mushroom may be underestimated by the observer's oversight
\end{tabular}

* Note that the number mushrooms may be underestimated by the observer's oversight 
Table 2: Observation time and the number of mycophagy events of each behavioral category

\begin{tabular}{|c|c|c|c|c|c|c|c|c|c|c|}
\hline \multirow[t]{2}{*}{ Month } & & \multicolumn{2}{|c|}{$\begin{array}{l}\text { Behavioral } \\
\text { observation (hour) }\end{array}$} & \multicolumn{6}{|c|}{ Number of mycophagy events } & \multirow{2}{*}{ Total } \\
\hline & & & & IG & $\mathrm{RE}$ & EX-A & EX-P & NE-A & NE-P & \\
\hline \multirow[t]{5}{*}{2009} & Aug & & 12 & 0 & 1 & 1 & 0 & 15 & 3 & 20 \\
\hline & Sep & & 21 & 0 & 0 & 0 & 0 & 0 & 0 & 0 \\
\hline & Oct & & 51 & 0 & 0 & 0 & 0 & 1 & 0 & 1 \\
\hline & Nov & & 57 & 0 & 1 & 0 & 0 & 1 & 2 & 4 \\
\hline & Dec & & 42 & 0 & 0 & 2 & 1 & 3 & 0 & 6 \\
\hline \multirow[t]{10}{*}{2010} & Jan & & 45 & 0 & 0 & 0 & 0 & 0 & 0 & 0 \\
\hline & Feb & & 27 & 0 & 1 & 0 & 0 & 5 & 1 & 7 \\
\hline & Mar & & 39 & 0 & 0 & 2 & 0 & 15 & 0 & 17 \\
\hline & Apr & & 111 & 0 & 0 & 1 & 0 & 34 & 3 & 38 \\
\hline & May & & 99 & 2 & 6 & 4 & 1 & 78 & 17 & 108 \\
\hline & Jun & & 45 & 3 & 5 & 4 & 5 & 44 & 3 & 64 \\
\hline & Jul & & 36 & 2 & 2 & 0 & 1 & 23 & 3 & 31 \\
\hline & Aug & & 57 & 0 & 0 & 3 & 0 & 22 & 3 & 28 \\
\hline & Sep & & 27 & 0 & 0 & 0 & 0 & 2 & 2 & 4 \\
\hline & & Total & 669 & 7 & 16 & 17 & 8 & 243 & 37 & 328 \\
\hline
\end{tabular}

All the data presented here was collected by focal observation on adult female macaques. Data include the cases where fungal samples were failed to be collected 
Table 3: Number of fungal samples, genera and species identified under each behavioral category

\begin{tabular}{|c|c|c|c|c|c|c|}
\hline \multicolumn{2}{|l|}{ Behavior } & \multicolumn{2}{|c|}{ All samples } & \multicolumn{3}{|l|}{ Identified } \\
\hline Category & Description & Sample & Genus & Sample & Genus & Species \\
\hline IG & Ignore (no touch) & 36 & 27 & 26 & 24 & 24 \\
\hline $\mathrm{RE}$ & Examine, not eat & 53 & 22 & 37 & 12 & 34 \\
\hline NE-A & Not examine, eat all & 210 & 33 & 116 & 24 & 51 \\
\hline NE-P & Not examine, eat partially & 57 & 23 & 37 & 19 & 26 \\
\hline EX-A & Examine, eat all & 19 & 9 & 9 & 6 & 7 \\
\hline EX-P & Examine, eat partially & 17 & 5 & 10 & 4 & 7 \\
\hline \multicolumn{2}{|c|}{ Total number of samples } & $392(25)$ & - & 235 (18) & - & - \\
\hline \multicolumn{2}{|c|}{ Genera or species foraged or ingored * } & - & $66(5)$ & - & $51(3)$ & $110(7)$ \\
\hline \multicolumn{2}{|c|}{ Genera or species consumed $* *$} & - & $41(4)$ & - & $31(3)$ & 67 (6) \\
\hline
\end{tabular}

Data were collected by all-occurrence sampling on both focal and non-focal animals

Samples with the maximum identify $\geq 97 \%$ were defined as identified

* Includes all the 6 behavioral categories (IG, RE, NE-A, NE-P, EX-A, EX-P)

** Either whole (NE-A, EX-A) or partial (NE-P, EX-P) consumption was observed. Numbers in parentheses are those only family, order, or class were available 


\section{Figure legends}

Figure 1: Home range of AT troop in the study area, on the western coastal area of Yakushima, Kagoshima Prefecture, Japan, estimated by the minimum convex polygon (MCP).

Figure 2: Seasonal variations in dietary composition (August 2009 - September 2010)

Figure 3: Proportion of poisonous mushrooms among each mycophagy behaviors.

The number of samples collected is shown in each bar. IG, ignore; NE-A, not examine and eat all; NE-P, not examine and eat partially; RE, reject; EX-A; examine and eat all; EX-P, examine and eat partially (see Table 1 for detailed behavioral description) 


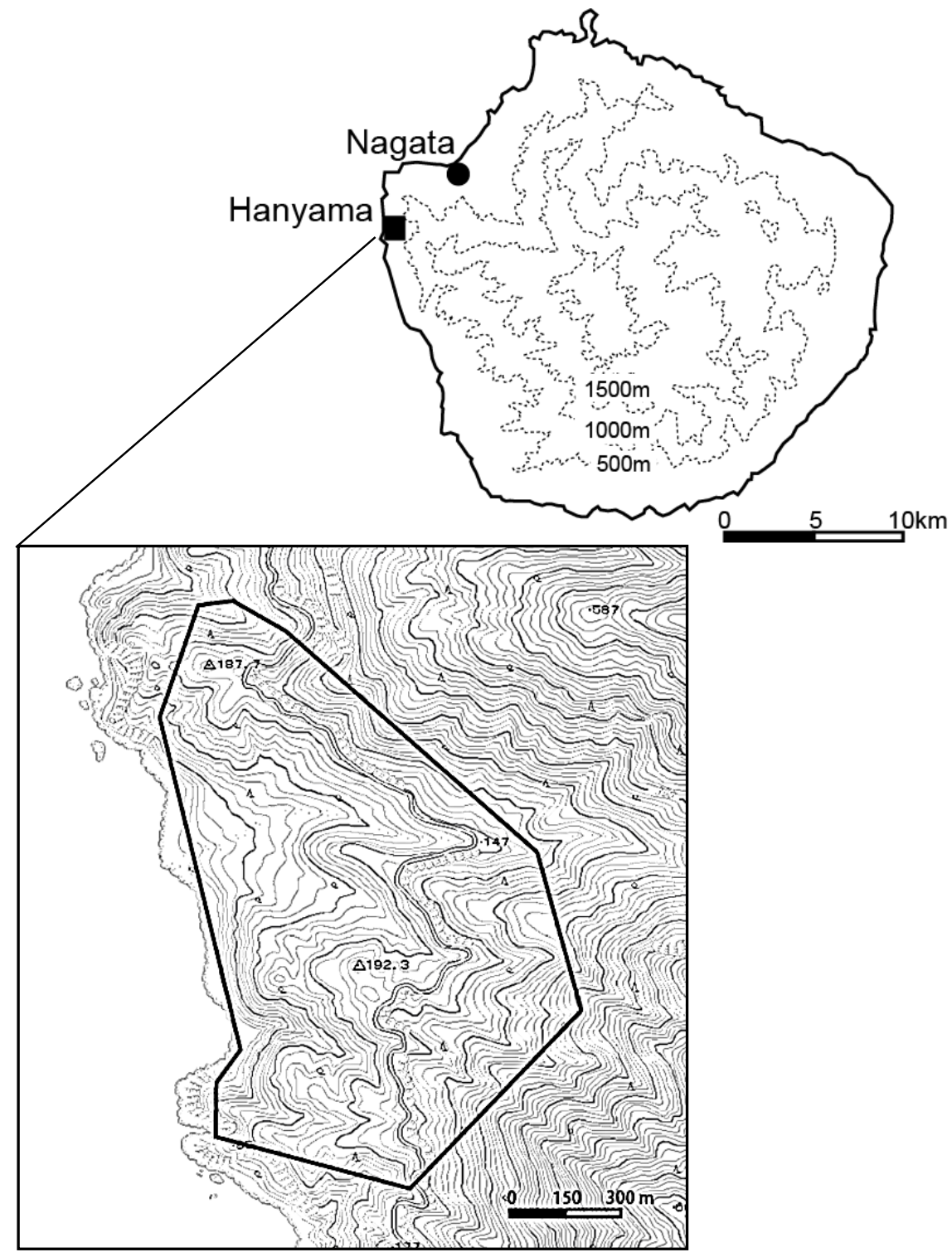

Figure 1 


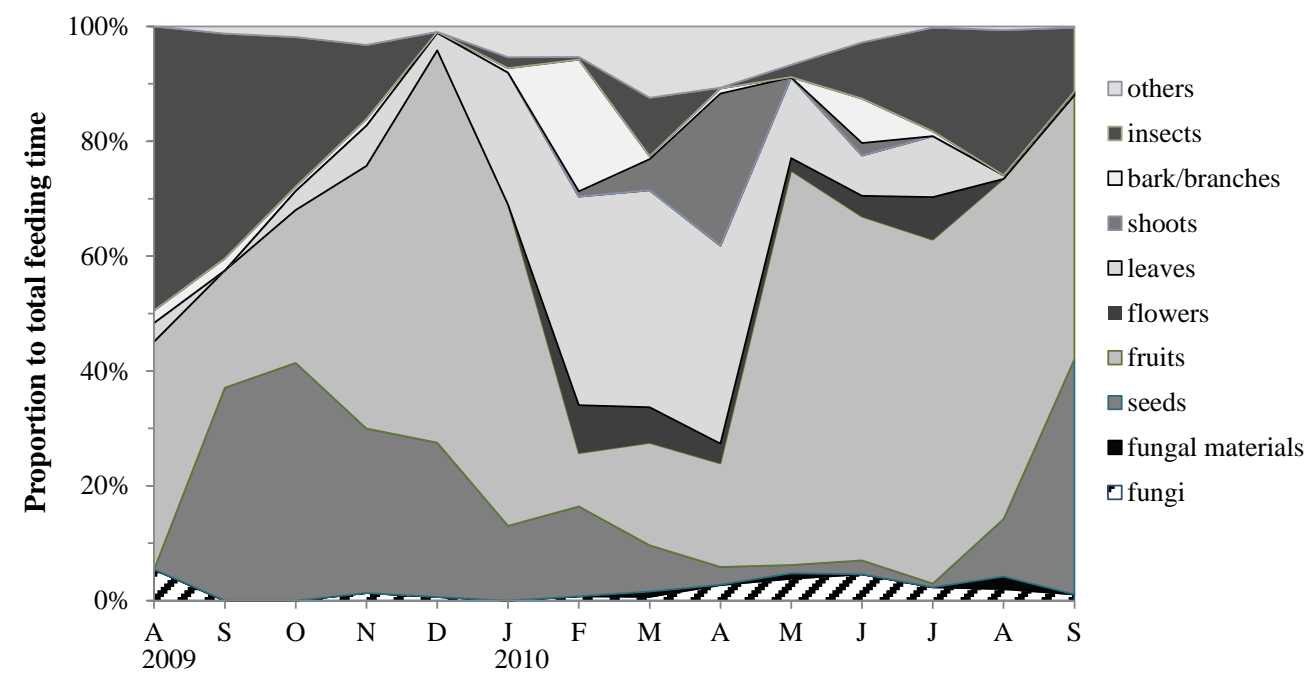

Figure 2 


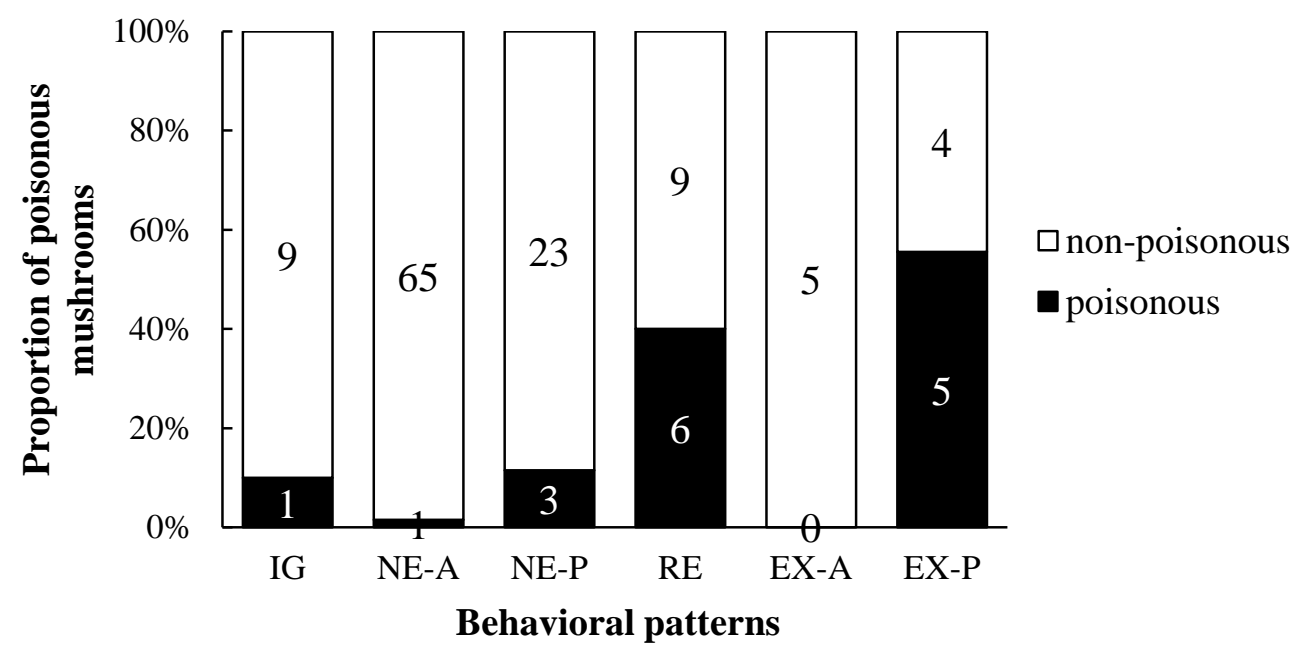

Figure 3 
Appendix. List of mushroom species foraged or ignored by Japanese macaques in Yakushima

\begin{tabular}{|c|c|c|c|c|c|c|c|c|c|c|c|c|c|c|c|c|c|c|c|c|c|c|c|}
\hline \multirow[t]{2}{*}{ Species } & \multirow{2}{*}{$\begin{array}{l}\text { Edibilityl } \\
\text { toxicity }\end{array}$} & \multicolumn{6}{|c|}{ Behavioral category } & \multirow[b]{2}{*}{ Total } & \multicolumn{15}{|c|}{ Sampling } \\
\hline & & IG & $\mathrm{RE}$ & NE-A & NE-P & EX-A & EX-P & & 2009 & & & & & & 2010 & & & & & & & & \\
\hline & & & & & & & & & 7 & 8 & 9 & 10 & 11 & 12 & 1 & 2 & 3 & 4 & 5 & 6 & 7 & 8 & 9 \\
\hline Agaricus moelleri & & & 1 & & & & & 1 & & & O & & & & & & & & & & & & \\
\hline Agaricus nivescens & NA & 1 & & & & & & 1 & O & & & & & & & & & & & & & & \\
\hline Agaricus subrutilescens & Edible & & 2 & & & & & 2 & O & & & & & & & & & & 0 & & & & \\
\hline Agrocybe aegerita & & & 1 & & & & & 1 & & & & & & & & & & & & O & & & \\
\hline Agrocybe chaxingu & & & 1 & 1 & & & & 2 & O & & & & & & & & & & & 0 & & & \\
\hline Agrocybe cylindracea & Edible & & & 1 & 4 & & & 5 & & O & & 0 & 0 & & & & & & O & O & & & \\
\hline Amanita alboflavescens & & & & 1 & & & & 1 & & & & & & & & & & & & & & O & \\
\hline Amanita esculenta & NA & & & 1 & & & & 1 & & & & & & & & 0 & 0 & & & & & & \\
\hline Amanita fritillaria & & & & & & 1 & & 1 & & & & & & & & & & & & O & & & \\
\hline Amanita griseoverrucosa & & & 1 & & & & & 1 & & O & & & & & & & & & & & & & \\
\hline Amanita imazekii & & & 1 & & & & & 1 & & 0 & & & & & & & & & & & & & \\
\hline Amanita orientigemmata & & & 1 & & & & & 1 & O & & & & & & & & & & & & & & \\
\hline Amanita pseudoporphyria & Poisonous & & 2 & & & & 1 & 3 & O & O & & & & & & & & & & & & & \\
\hline Amanita sepiacea & NA & & 1 & & & & 1 & 2 & & & & & & & & & & & 0 & & & & \\
\hline Amanita solitaria & & & 1 & & & & & 1 & O & & & & & & & & & & & & & & \\
\hline Amanita spissacea & Poisonous & & 1 & & 1 & & 4 & 6 & O & & & & & & & & & & & O & & & \\
\hline Amanita virgineoides & NA & & 1 & & & & & 1 & & & & & & & & & & & & & & & 0 \\
\hline Amanita sp. A & & 1 & 1 & & 1 & & & 3 & & & & & & & & & & & O & O & & & \\
\hline Amanita sp. B & & & 1 & & & & & 1 & 0 & & & & & & & & & & & & & & \\
\hline Amauroderma rugosum & & & & & 1 & & & 1 & & & & & & & & & & & & O & & & \\
\hline Armillaria mellea & & & & & 1 & & & 1 & & & & & & O & & & & & & & & & \\
\hline Auricularia aff. auricula-judae & Edible & & & 3 & & & & 3 & & & & & & & & & & & & O & & O & 0 \\
\hline Auricularia auricula-judae & Edible & & & 4 & & & & 4 & & & & & & & & 0 & & & O & 0 & & & \\
\hline Auricularia polytricha & Edible & & & 8 & 1 & & & 9 & & 0 & & & & & & 0 & & 0 & O & & & & \\
\hline Boletus fraternus & & & & 1 & & & & 1 & & & & & & & & & & & & 0 & & & \\
\hline
\end{tabular}




\begin{tabular}{|c|c|c|c|c|c|c|c|c|c|c|c|c|c|c|c|c|c|c|c|c|c|c|c|}
\hline \multirow[t]{2}{*}{ Species } & \multirow{2}{*}{$\begin{array}{l}\text { Edibility/ } \\
\text { toxicity }\end{array}$} & \multicolumn{6}{|c|}{ Behavioral category } & \multirow[b]{2}{*}{ Total } & \multicolumn{15}{|c|}{ Sampling } \\
\hline & & IG & $\mathrm{RE}$ & NE-A & NE-P & EX-A & EX-P & & 2009 & & & & & & 2010 & & & & & & & & \\
\hline & & & & & & & & & 7 & 8 & 9 & 10 & 11 & 12 & 1 & 2 & 3 & 4 & 5 & 6 & 7 & 8 & 9 \\
\hline Campanella alba & & & 1 & & & & & 1 & & & & & & & & & & & 0 & & & & \\
\hline Chaetocalathus galeatus & & 1 & & & & & & 1 & & & & & & & & & 0 & & & & & & \\
\hline Collybia confluens & & 1 & & & & & & 1 & & & & & & & & & & & & 0 & & & \\
\hline Collybia sp. & & & 1 & & & & & 1 & & & & & & & & & & & & 0 & & & \\
\hline Conocybe lactea & NA & & 1 & & & & & 1 & & & & & & & & & & & & & & 0 & \\
\hline Coriolopsis strumosa & & & & 2 & & & & 2 & & & & & & & & & & & & 0 & & & \\
\hline Crepidotus mollis & NA & & & 22 & 4 & & 1 & 27 & O & & & & O & & & & 0 & 0 & 0 & 0 & & 0 & \\
\hline Crepidotus sp. & & & & 1 & & & & 1 & & & & & & & & & & & O & & & & \\
\hline Cyptotrama asprata & & 1 & & & & & & 1 & & & & & & & & & & & 0 & & & & \\
\hline Dictyopanus gloeocystidiatus & & 1 & & & & & & 1 & & & & & & & & & & & & 0 & & & \\
\hline Entoloma sp. & & & & 2 & & & 1 & 3 & O & & & & & & & & & & 0 & & & & \\
\hline Filoboletus manipularis & NA & 2 & & & & & & 2 & & & & & & & & & & & 0 & & & & \\
\hline Ganoderma mastoporum & & 1 & & & & & & 1 & O & & & & & & & & & & & & & & \\
\hline Gymnopilus crociphyllus & & 1 & & & & & & 1 & & & & & & & & & & & 0 & & & & \\
\hline Gymnopilus liquiritiae & NA & & & 2 & 1 & & & 3 & & & & & & & & & & & 0 & & & & \\
\hline Hericium coralloides & & & 1 & & & & & 1 & & & & & & & & & & & O & & & & \\
\hline Hohenbuehelia sp. & & & & 1 & & & & 1 & & & & & & & & & & & & 0 & & & \\
\hline Hygrocybe reidii & & 1 & & & & & & 1 & & & & & & & & & & 0 & & & & & \\
\hline Hypholoma fasciculare & Poisonous & & & 1 & 1 & & & 2 & 0 & & & & & & & & & & & & & 0 & \\
\hline Inocybe sphaerospora & NA & 1 & & & & & & 1 & & & & & & & & & & & & & O & & \\
\hline Lactarius furcatus & & & 1 & & & & & 1 & 0 & & & & & & & & & & & & & & \\
\hline Lactarius gerardii & NA & & 1 & & & & & 1 & & & & & & & & & & & & & 0 & & \\
\hline Leccinum sp. & & & & 2 & & & & 2 & & & & & & & & & & & & & 0 & 0 & \\
\hline Lentinula edodes & Edible & & & & 1 & & & 1 & & & & 0 & & & & & & & & & & & \\
\hline Lenzites elegans & & 1 & & & & & & 1 & & & & & & & & & O & & & & & & \\
\hline Marasmiaceae sp. A* & & & & 4 & 1 & & & 5 & & & & & & & & & & 0 & & 0 & & 0 & \\
\hline Marasmiaceae sp. B * & & 1 & & & & & & 1 & & & & & & & & & & & & 0 & & & \\
\hline
\end{tabular}




\begin{tabular}{|c|c|c|c|c|c|c|c|c|c|c|c|c|c|c|c|c|c|c|c|c|c|c|c|}
\hline \multirow[t]{3}{*}{ Species } & \multirow{3}{*}{$\begin{array}{l}\text { Edibility/ } \\
\text { toxicity }\end{array}$} & \multicolumn{6}{|c|}{ Behavioral category } & \multirow[b]{2}{*}{ Total } & \multicolumn{15}{|c|}{ Sampling } \\
\hline & & IG & $\mathrm{RE}$ & NE-A & NE-P & EX-A & EX-P & & \multicolumn{2}{|l|}{2009} & \multirow[b]{2}{*}{9} & \multirow[b]{2}{*}{10} & \multirow[b]{2}{*}{11} & \multicolumn{3}{|c|}{2010} & \multirow[b]{2}{*}{3} & \multirow[b]{2}{*}{4} & \multirow[b]{2}{*}{5} & \multirow[b]{2}{*}{6} & \multirow[b]{2}{*}{7} & \multirow[b]{2}{*}{8} & \\
\hline & & & & & & & & & 7 & 8 & & & & 12 & 1 & 2 & & & & & & & 9 \\
\hline Microporus vernicipes & NA & 1 & & & & & & 1 & O & & & & & & & & & & & & & & \\
\hline Oudemansiella aff. platyphylla & Poisonous & & 1 & & & & & 1 & & & & & & & & & & & & & & O & \\
\hline Oudemansiella canarii & & & & 3 & 3 & & & 6 & & & & & & & & & & & $\mathrm{O}$ & & & O & 0 \\
\hline Oudemansiella mucida & Edible & & 1 & 2 & 1 & 2 & & 6 & & & & & 0 & & & & & $\mathrm{O}$ & & O & & 0 & \\
\hline Perenniporia ochroleuca & & 1 & & & & & & 1 & & & & & & & & & & & & O & & & \\
\hline Phallus impudicus & & & & 1 & & & & 1 & & & & & & & & & & & 0 & & & & \\
\hline Phylloporus aff. bellus & Poisonous & 1 & 1 & & 1 & & & 3 & & & & & & & & & & & $\mathrm{O}$ & & $\mathrm{O}$ & & \\
\hline Pleuroflammula praestans & & & & 1 & & & & 1 & & & & & & & & & $\mathrm{O}$ & & & & & & \\
\hline Pleurotus cornucopiae & Edible & & & 1 & & & & 1 & & & & & & & & & $\mathrm{O}$ & & & & & & \\
\hline Pleurotus djamor & & & & 1 & & & & 1 & & & & & & & & & & & 0 & & & & \\
\hline Pleurotus sp. & & 1 & & 1 & 1 & 1 & & 4 & & & & O & & & & O & & & & & & & \\
\hline Pluteus granulatus & & & & & & 1 & & 1 & & & & & & & & & & 0 & & & & & \\
\hline Polyporaceae sp. * & & & & 1 & & & & 1 & & & & & & & & & & & & 0 & & & \\
\hline Polyporus aff. alveolaris & NA & 1 & & 4 & 1 & & & 6 & & & & & & & & & & 0 & 0 & 0 & & & \\
\hline Polyporus tuberaster & NA & & & & & 2 & & 2 & & & & & & & & & & & O & & & & \\
\hline Psathyrella candolleana & Edible & & & & 1 & & & 1 & & & & & & & & & & & & & & 0 & \\
\hline Rhodophyllus chamaecyparidis & & & 2 & & & & & 2 & O & & & & & & & & & & & 0 & & & \\
\hline Russula aff. alboareolata & NA & & & 3 & & & 1 & 4 & 0 & & & & & & & & & & & & & 0 & 0 \\
\hline Russula aff. flavida & NA & & & & 1 & & & 1 & & O & & & & & & & & & & & & & \\
\hline Russula alboareolata & NA & & & 5 & 1 & & & 6 & O & & & & & & & & & & & O & $\mathrm{O}$ & O & 0 \\
\hline Russula cf. nigricans & Edible & & 1 & & & & & 1 & & & & & & & & & & & & 0 & & & \\
\hline Russula citrina & & & & 2 & & & & 2 & & & & & & & & O & O & & & & & & \\
\hline Russula cyanoxantha & Edible & & & 1 & & 1 & & 2 & & & & & & & & & & & & 0 & & & \\
\hline Russula heterophylla & & & & 1 & & & & 1 & 0 & & & & & & & & & & & & & & \\
\hline Russula japonica & Poisonous & & 1 & & & & & 1 & O & & & & & & & & & & & & & & \\
\hline Russula lepida & & & & 1 & & & & 1 & O & & & & & & & & & & & & & & \\
\hline Russula mariae & & & & 1 & & & & 1 & & 0 & & & & & & & & & & & & & \\
\hline
\end{tabular}




\begin{tabular}{|c|c|c|c|c|c|c|c|c|c|c|c|c|c|c|c|c|c|c|c|c|c|c|c|}
\hline \multirow[t]{3}{*}{ Species } & \multirow{2}{*}{$\begin{array}{l}\text { Edibility/ } \\
\text { toxicity }\end{array}$} & \multicolumn{6}{|c|}{ Behavioral category } & \multirow[b]{2}{*}{ Total } & \multicolumn{15}{|c|}{ Sampling } \\
\hline & & IG & $\mathrm{RE}$ & NE-A & NE-P & EX-A & EX-P & & 2009 & & & & & & 2010 & & & & & & & & \\
\hline & & & & & & & & & 7 & 8 & 9 & 10 & 11 & 12 & 1 & 2 & 3 & 4 & 5 & 6 & 7 & 8 & 9 \\
\hline Russula pectinatoides & NA & & 1 & & & & & 1 & & & & & & & & & & & 0 & & & & \\
\hline Russula vesca & NA & & & 1 & & & 1 & 2 & 0 & 0 & & & & & & & & & & & & & \\
\hline Russula sp. A & & & 1 & & & & & 1 & 0 & & & & & & & & & & & & & & \\
\hline Russula sp. B & & & & 2 & & & & 2 & & & & & & & & 0 & 0 & & & & & & \\
\hline Russula sp. C & & & 1 & & & & & 1 & 0 & & & & & & & & & & & & & & \\
\hline Russula sp. D & & & & & 1 & & & 1 & & & & & & & & & & & & & & 0 & \\
\hline Russula sp. E & & & 1 & 3 & & & & 4 & & & & & & & & & & & & 0 & & & 0 \\
\hline Russula sp. F & & & 1 & & & & & 1 & 0 & & & & & & & & & & & & & & \\
\hline Russula sp. G & & & 1 & 1 & 1 & 1 & & 4 & 0 & & & & & & & & & & 0 & & & & \\
\hline Russula sp. H & & & 1 & & & & & 1 & & & & & & & & & & & & & $\mathrm{O}$ & & \\
\hline Russula sp. I & & & & 1 & & & & 1 & & & & & & & & & & & 0 & & & & \\
\hline Russula sp. J & & & & 1 & 2 & & & 3 & 0 & & & & & & & & & & & & & 0 & \\
\hline Russula sp. K & & & & 1 & & & & 1 & & & & & & & & & & & & & 0 & & \\
\hline Russula sp. L & & & & 1 & & & & 1 & & & & & & & & & & & 0 & & & & \\
\hline Russula sp. $M$ & & & & 1 & & & & 1 & & & & & & & & & & & & 0 & & & \\
\hline Russula sp. N & & & 1 & & & & & 1 & 0 & & & & & & & & & & & & & & \\
\hline Russulaceae sp. A* & & & & 2 & & & & 2 & & & & & & & & & & & 0 & & & & \\
\hline Russulaceae sp. B * & & 1 & & 5 & & & & 6 & 0 & & & & & & & & & & 0 & & & & \\
\hline Russulaceae sp. C * & & & & 1 & & & & 1 & & 0 & & & & & & & & & & & & & \\
\hline Russulaceae sp. D* & & & & 2 & & & & 2 & & & & & & & & & & 0 & 0 & & & & \\
\hline Schizophyllum commune & & & & 3 & & & & 3 & & & & & & & & O & & 0 & 0 & & & & \\
\hline Simocybe serrulate & & 1 & & & & & & 1 & & & & & & & & & & & 0 & & & & \\
\hline Stereum ostrea & NA & & & 3 & 2 & & & 5 & & & & & & & & & & 0 & 0 & 0 & & & \\
\hline Strobilomyces seminudes & NA & 1 & & & 1 & & & 2 & & & & & & & & & & & & 0 & 0 & & \\
\hline Trichaptum biforme & NA & 2 & & & & & & 2 & & & & & & & & & & 0 & 0 & & & & \\
\hline Tylopilus ballouii & & & & 1 & & & & 1 & & & & & & & & & & & & & & 0 & \\
\hline Tylopilus sp. & & & & 1 & & & & 1 & & & & & & & & & & & & 0 & & & \\
\hline
\end{tabular}




\begin{tabular}{|c|c|c|c|c|c|c|c|c|c|c|c|c|c|c|c|c|c|c|c|c|c|c|c|c|}
\hline \multirow[t]{2}{*}{ Species } & \multirow{2}{*}{$\begin{array}{l}\text { Edibilityl } \\
\text { toxicity }\end{array}$} & \multicolumn{6}{|c|}{ Behavioral category } & \multirow[b]{2}{*}{ Total } & \multicolumn{16}{|c|}{ Sampling } \\
\hline & & IG & $\mathrm{RE}$ & NE-A & NE-P & EX-A & EX-P & & 2009 & & & & & & 201 & & & & & & & & & \\
\hline & & & & & & & & & 7 & 8 & 9 & 10 & 11 & 12 & 1 & 2 & 3 & & 4 & 5 & 6 & 7 & 8 & 9 \\
\hline Xerocomus chrysenteron & Edible & & & 1 & 1 & & & 2 & & & & & & & & & & & & 0 & & & & \\
\hline Xerocomus subtomentosus & & & & 1 & & & & 1 & & & & & & & & & & & & & & & 0 & \\
\hline Xerocomus $s p$. & & 1 & & & & & & 1 & & & & & & & & & & & & & & 0 & & \\
\hline Zelleromyces sp. & & 1 & & & & & & 1 & & & & & & & & & $c$ & & & & & & & \\
\hline
\end{tabular}

Numbers in behavioral categories indicate the number of mycophagy events where mushroom samples were available. ${ }^{*}=$ mushrooms identified only to the family level. $\mathrm{NA}=$ no information on edibility/toxicity provided by the reference book. Blank $=$ species not addressed under the reference book. 